Utah State University

DigitalCommons@USU

\title{
Employment Stability and the Role of Sectoral Dominance in Rural Economies
}

\author{
Christopher Fawson \\ Utah State University \\ Dawn Thilmany \\ Utah State University \\ John E. Keith \\ Utah State University
}

Follow this and additional works at: https://digitalcommons.usu.edu/eri

\section{Recommended Citation}

Fawson, Christopher; Thilmany, Dawn; and Keith, John E., "Employment Stability and the Role of Sectoral Dominance in Rural Economies" (1996). Economic Research Institute Study Papers. Paper 98.

https://digitalcommons.usu.edu/eri/98

This Article is brought to you for free and open access by the Economics and Finance at DigitalCommons@USU. It has been accepted for inclusion in Economic Research Institute Study Papers by an authorized administrator of DigitalCommons@USU. For more information, please contact digitalcommons@usu.edu.

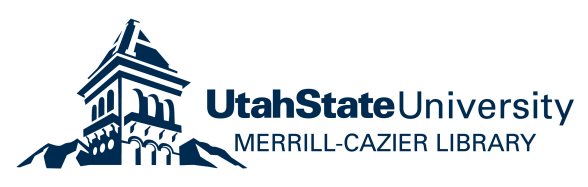


Economic Research Institute Study Paper

ERI \#96-32

\section{EMPLOYMENT STABILITY AND THE ROLE OF SECTORAL DOMINANCE IN RURAL ECONOMIES}

by

CHRISTOPHER FAWSON

DAWN THILMANY

JOHN E. KEITH

Department of Economics

Utah State University

3530 University Boulevard

Logan, UT 84322-3530

December 1996 


\title{
EMPLOYMENT STABILITY AND THE ROLE OF SECTORAL DOMINANCE IN RURAL ECONOMIES
}

\author{
Christopher Fawson, Associate Professor \\ Dawn Thilmany, Assistant Professor \\ John E. Keith, Professor \\ Department of Economics \\ Utah State University \\ 3530 University Boulevard \\ Logan, UT 84322-3530
}

The analyses and views reported in this paper are those of the author(s). They are not necessarily endorsed by the Department of Economics or by Utah State University.

Utah State University is committed to the policy that all persons shall have equal access to its programs and employment without regard to race, color, creed, religion, national origin, sex, age, marital status, disability, public assistance status, veteran status, or sexual orientation.

Information on other titles in this series may be obtained from: Department of Economics, Utah State University, 3530 University Boulevard, Logan, Utah 84322-3530.

Copyright () 1996 by Christopher Fawson, Dawn Thilmany, and John E. Keith. All rights reserved. Readers may make verbatim copies of this document for noncommercial purposes by any means, provided that this copyright notice appears on all such copies. 


\title{
EMPLOYMENT STABILITY AND THE ROLE OF SECTORAL DOMINANCE IN RURAL ECONOMIES \\ Christopher Fawson, Dawn Thilmany, and John E. Keith
}

\begin{abstract}
Tourism-based rural economic development schemes are of great interest to many states that once relied on extractive industries, particularly in the West. This study analyzes the potential labor market implications of such development strategies, with a focus on employment stability and persistence. Although trade and service employment has increased significantly, strong low-frequency cycles underlie these labor markets. In short, it is imperative that rural economic development strategies account for the role of sectoral dominance in evaluating the trade-off between low-frequency and high-frequency employment cycles.
\end{abstract}




\section{EMPLOYMENT STABILITY AND THE ROLE OF SECTORAL DOMINANCE IN RURAL ECONOMIES ${ }^{1}$}

\section{Introduction}

There has been considerable interest in alternative strategies for rural development during the past decade, particularly as markets have become globalized and extractive resource-based economies have become subject to growing competition (Barkley; Markley, and McNamara; Kraybill and Weber). With increasing environmental pressure on public land managers and a diminishing comparative advantage in the world resource markets, extractive industries in the rural West have declined, bringing lagging economic bases, declining employment, and decreasing incomes. Various rural economic development strategies have been proposed to alleviate these economic concerns. In many cases, rural communities attempt to focus transitional development strategies on recreation and tourism in order to capitalize on a perceived comparative advantage in rural lifestyles and quality-of-life trends.

Environmental groups, as well as some economic researchers, have suggested that those rural areas with recreation and/or tourism potential have experienced relatively rapid growth fueled by expanding service sectors. (Glasmeier and Holland; Drabenstott). Some studies have suggested that tourism and recreation provide the "new" paradigm for rural development (Rudzitis and Johansen; Powers 1990, 1996). Other studies have used input/output techniques to suggest that significant economic growth can be derived from tourism and recreation visitors (Bergstrom et al. 1990a, 1990b; Cordell, Bergstrom, and Watson; Dawson, Blahna, and Keith).

\footnotetext{
${ }^{1}$ The authors express their gratitude to members of NE-162 for helpful comments and the Utah Department of Employment Security for providing labor data. This work was supported by the Utah Agricultural Experiment Station and approved as journal paper \#4984.
} 
However, the recreation and tourism development scheme is not readily accepted as a panacea for rural areas. Specifically, Brown and Pheasant have pointed out the relative instability of trade and service sectors in rural economies. Neumann and Topel suggest that significant differences in employment risk across geographic regions (state level in their case) are primarily due to the sectoral composition and the diversification of economies. Although worker mobility allows for some equilibrating among regional markets, unemployment risk is relatively greater in those regions dominated by industries known to be relatively cyclical in nature. Given this general finding, similar results are expected among rural counties with varying labor market compositions. In earlier work (Keith and Fawson; Fawson, Keith, and Chang), the cyclic nature of employment was examined for counties in Utah with different economic bases, focusing on mining, manufacturing, and recreation/tourism.

Most rural economies lack the basic resources and infrastructure to develop a diversified economic base. As such, small isolated economies that are dominated by strong sectoral dependencies are likely to exhibit patterns of economic stability, which are characteristic of the underlying dominant sector. The focus of this research is on the dynamics of employment persistence and job gain and job loss permanence in rural labor markets. Specifically, this study examines two measures of employment stability in rural counties of Utah, which will be used in a comparative analysis of counties with differing economic bases, including extractive industry (mining), tourism/recreation and retirement (trade and service), manufacturing, and government.

Our analysis begins with a description of the empirical methodology. We then identify the primary industry employment base in each county. The findings of nonparametric methods are then presented. Subsequently, measures of employment stability were compared across counties with differing employment bases, followed by a discussion of the results and their policy implications. 


\section{Methodology}

Two fundamentally different methodologies are used to evaluate systematic differences in employment profiles across Utah counties. Utah provides an interesting case for analysis because of the diversity of economic development regimes which exist at the county level. In particular, as Utah's rural counties grapple with the milieu of federal land management issues, which significantly affect their traditional natural resource base economies, the historic debate over rural vs. urban development agendas has become more poignant.

The first approach used to analyze the stability of employment profiles across differing employment bases follows the hazard rate methodology presented in Clark, Gertler, and Whiteman, which involves the specification of a heuristic rule to examine a pattern of the permanence of job creation and job loss. For any given observation, the change in employment from one month to the next is calculated by taking the first difference of the employment series. If that change is positive, new jobs are "created"; if negative, jobs are "lost." For jobs created (lost) in a given month, each successive month is examined to determine when those jobs were lost (regained). The heuristic algorithm allocated job gains (losses), according to the rule of "last hired, first fired" for allocating job gains, and "first fired, first hired" for job losses. Thus, if a job is created in month 1 and another in month 2, followed by a job loss in month 3 and a job loss in month 4, it is assumed that the job created in month 1 had persisted to month 4 (3-month employment duration), while the job created in month 2 persisted until month 3 (1-month employment duration). For jobs lost, if a job is lost in month 1 and another lost in month 2, followed by a job gain in month 3 and a job gain in month 4 , it is assumed that the job lost in month 1 had persisted to month 3 (2-month unemployment duration) and the job lost in month 2 persisted until month 4 (also a 2-month unemployment duration). Once job gains and losses are allocated to respective subsequent periods, the proportion of jobs gained 
(lost), which are lost (gained) in successive months, is calculated. The conditional probability of losing (recapturing) a job after a given period is calculated from the relative frequencies. Finally, the cumulative conditional probability of job creation duration or job loss duration for a given number of months is calculated.

The job gain (loss) allocation heuristic is defined by the following steps:

Step 1. Take the first difference of the employment series.

$\mathrm{J}_{\mathrm{i}, \mathrm{t}}=\mathrm{E}_{\mathrm{i}, \mathrm{t}}-\mathrm{E}_{\mathrm{i}, \mathrm{t}-\mathrm{l}}, \quad$ where $\mathrm{J}_{\mathrm{i}, \mathrm{t}}$ denotes job gain $\left(\mathrm{J}_{\mathrm{i}, \mathrm{t}}>0\right)$ or job loss $\left(\mathrm{J}_{\mathrm{i}, \mathrm{t}}<0\right)$ in industry $\mathrm{i}$ at time $\mathrm{t}$, and $\mathrm{E}_{\mathrm{i}, \mathrm{t}}$ denotes employment in industry $\mathrm{i}$ at time $\mathrm{t}$.

Step 2. Allocate the dissipation of job gains and job losses to subsequent time periods.

$\mathrm{JC}_{\mathrm{i}, \mathrm{t}, \mathrm{s}}$ denotes the number of jobs in industry $\mathrm{i}$ which are gained in period $\mathrm{t}$ and lost $\mathrm{s}$ periods later.

$\mathrm{JL}_{\mathrm{i}, \mathrm{ts}}$ denotes the number of jobs in industry $\mathrm{i}$ which are lost in period $\mathrm{t}$ and regained $\mathrm{s}$ periods later.

Step 3. Calculate the relative frequency domain of job loss and job gains by duration. $\mathrm{RJC}_{\mathrm{i}, \mathrm{t,s}}=\mathrm{JC}_{\mathrm{i}, \mathrm{ts}} / \mathrm{J}_{\mathrm{i}, \mathrm{t}}, \quad$ for all $\mathrm{J}_{\mathrm{i}, \mathrm{t}}>0$ where $\mathrm{RJC}_{\mathrm{i}, \mathrm{ts}}$ denotes the proportion of jobs in industry $\mathrm{i}$ which are gained in period $\mathrm{t}$ and lost s periods later.

$\mathrm{RJL}_{\mathrm{i}, \mathrm{t}, \mathrm{s}}=\mathrm{JL}_{\mathrm{i}, \mathrm{t}, \mathrm{s}} / \mathrm{J}_{\mathrm{i}, \mathrm{t}}, \quad$ for all $\mathrm{J}_{\mathrm{i}, \mathrm{t}}<0$ where $\mathrm{RJC}_{\mathrm{i}, \mathrm{ts}}$ denotes the proportion of jobs in industry $\mathrm{i}$ which are lost in period $\mathrm{t}$ and regained s periods later.

Step 4. Summarize the relative frequency domain in the context of a point estimator (mean).

Mean_RJC $\mathrm{i}_{\mathrm{i}, \mathrm{s}}=\Sigma_{\mathrm{t}} \mathrm{RJC}_{\mathrm{i}, \mathrm{ts}} / \mathrm{n}_{\mathrm{C}}, \quad$ where $\mathrm{n}_{\mathrm{C}}$ denotes the number of observations that satisfy $\mathrm{RJC}_{\mathrm{i}, \mathrm{s}, \mathrm{s}}>0$; and Mean_RJC $\mathrm{i}_{\mathrm{i}, \mathrm{s}}$ denotes the mean 
conditional probability of a job gain in any period having a duration of exactly s periods.

Mean_RJL $L_{i, s}=\Sigma_{t} R_{L} L_{i, t s} / n_{L}, \quad$ where $n_{L}$ denotes the number of observations that satisfy $\mathrm{RJL}_{\mathrm{i}, \mathrm{s}, \mathrm{s}}>0$; and Mean_RJL $\mathrm{R}_{\mathrm{i}, \mathrm{s}}$ denotes the mean conditional probability of a job loss in any period having a duration of exactly s periods.

Step 5. Calculate implicit measures of the permanence of job gains or losses.

$\mathrm{CRJC}_{\mathrm{i}, \mathrm{v}}=1-\left[\Sigma_{\mathrm{s}}^{\mathrm{v}}\right.$ Mean_RJC $\left.\mathrm{C}_{\mathrm{i}, \mathrm{s}}\right], \quad$ where $\mathrm{CRJC}_{\mathrm{i}, \mathrm{v}}$ denotes the cumulative conditional probability of job retention duration lasting at least $\mathrm{v}$ periods after a job gain.

$\mathrm{CRJL}_{\mathrm{i}, \mathrm{v}}=1-\left[\Sigma_{\mathrm{s}}^{\mathrm{v}}\right.$ Mean_RJL $\left.\mathrm{L}_{\mathrm{i}, \mathrm{s}}\right], \quad$ where $\mathrm{CRJL}_{\mathrm{i}, \mathrm{v}}$ denotes the cumulative conditional probability of job loss duration lasting at least $\mathrm{v}$ periods after a job loss.

An index for job creation (loss) permanence is calculated by taking the simple mean of $\mathrm{CRJC}_{\mathrm{i}, \mathrm{v}}$ $\left(\mathrm{CRJL}_{\mathrm{i}, \mathrm{v}}\right)$ across counties which are dominated by common industry employment categories.

The second approach used to examine the stability of employment profiles across differing employment bases follows the methodology commonly used in the macroeconomic literature to measure random and persistent shocks to GNP (Cochrane). In short, persistence is indirectly calculated using the variance of the long differences in employment. The measure inherently assumes that there are temporary and permanent components to economic shocks (i.e., job creation or layoffs). The permanent component of the shock can be inferred from long-run persistence levels. 
The persistence measure is calculated as follows: for any interval of $k$ periods, $\Delta \mathrm{E}_{k}=\mathrm{E}_{\mathrm{t}}$ $\mathrm{E}_{\mathrm{t}-k}$, variance of employment for the interval is $\sigma_{k}^{2}$, and the variance of first differences over the total series is $\sigma_{1}{ }^{2}$. The average variance over the interval is $\sigma_{k}^{2} / k$. The measure of relative persistence for the $k^{\text {th }}$ interval, or "window," is $\sigma_{k}^{2} / k / \sigma_{1}^{2}$; the average variance of employment over a specified interval relative to the total variance normalized by the first differences. Thus, for a given a employment shock, if the persistence measure approaches 0 , the employment shock is dissipated in the interval. The larger the measure, the more persistent is the shock within the interval. The persistence measure is calculated over a set of intervals of monthly employment to test for persistence over time in total employment and employment by sector.

The two methodologies are complementary in their approach and expected results. The job allocation heuristic analyzes the gain or loss of any specific job observation throughout the sample period to measure the permanence of any gains or losses. However, it does not control for the economic growth that occurs over time. The employment persistence measure controls for such growth, and more accurately measures cyclical patterns in the labor market. Thus, the empirical discussion will be based on a joint interpretation of the two sets of findings.

\section{County Profiles and Identification}

In order to examine the stability of employment profiles across differing employment bases, it was necessary to identify those sectors within each of the counties on which the county economy "depended" in one sense or another. We categorized this "dependency" using county monthly employment data (ES202) for the period of 1974 to 1992 . Counties, in which the mean monthly employment share for a specific sector exceeded by one standard deviation the mean monthly employment share for that category across all counties in the total sample, were classified as being 
"relatively dependent on," or "specialized in" that employment category (see Table 1). ${ }^{2}$ Clearly, mining, government, and manufacturing sectors are specifically identified in county employment data (ES202 data).

However, recreation/tourism and retirement are not so clearly defined. In general, both activities impact the wholesale, retail, finance and real estate, and service sectors in the economy. Chadwick, in his survey of tourism research, presents a relatively clear definition of the sectors in which tourism and recreation have important expenditures: retail trade, hotels and motels, restaurants, transportation, and some governmental activities. It is obvious that these sectors are also directly impacted by other activities, such as retirement growth, and indirectly impacted by growth or decline in other sectors, such as income and/or employment decline. For this study, the trade and service sectors were taken to be indicative of a recreation and tourism base. Table 2 indicates the groupings of counties. Based on this criteria, there were five counties in the mining-dependent category, six counties in the manufacturing- and utility-dependent category, three counties in the recreation- and tourism-dependent (trade and service) category, and five counties in the government-dependent category.

In order to verify our categorization of "recreation- and tourism- dependent," we consulted a tourism financing document prepared by the Utah State Office of Planning and Budget (UOPB), in which counties were determined to be "tourism-dependent" if the annual transient room tax collected was greater than or equal to $3 \%$ of annual total personal income for a county. According to this document, using 1993 transient room tax data, ten counties are "tourism-dependent," of which

\footnotetext{
${ }^{2}$ The absolute largest employment in each county could not be used as a classification tool because trade and services tend to dominate any given local economy. For this reason, this study chose to classify economies based on their relative dependence on various economic activities.
} 
three are unclassified by our categorization. We assigned these three counties to the recreation and tourism specialization category, in addition to the counties selected by our criterion. ${ }^{3}$

As a final check on our classification, we examined the U.S. Department of Agriculture categorization of counties [USDA]. There were some differences in the USDA classification, resulting primarily from the characteristics of public land states (high government employment relative to the rest of the U.S.). Our mining characterization was the same as USDA's with the exception of one county, which the USDA classified as "No Specialty," or "other" in our classification. The USDA classification had only one county in the manufacturing/utilities category where our classification identified six. The others were classified as government (two), other, farm, or service (one each). For those counties that were classified as trade- and service-dependent using our classification, one county was classified by the USDA as government. In our government category, two counties were classified by the USDA as farm. Three counties did not satisfy either our ad hoc employment criteria or the state criteria for "tourism" dependency (although one was quite close to the "tourism" dependency percentage), and were classified as no specialty by the USDA. Since we did not include farming as a category (the data were not available in the ES202 series), the farming counties were reclassified using our criteria. In addition, our categorization was more sensitive to the characteristics of Utah and other states with a large share of federal lands.

\section{Results}

Permanence Measures. Summary measures of total employment job loss are presented in Table 3. Counties dominated by mining employment have the largest average index of job loss permanence, indicating long-term employment declines in those counties and reflecting the

\footnotetext{
${ }^{3}$ Note that these three counties were "closer" to the recreation and tourism class than any other classification. Also note that, using 1983-1993 data, Grand County would have been classified in the"recreation and tourism" group.
} 
long-cycle employment patterns of extractive resource-dependent economies. Counties, which are dominated by trade and service employment, have the smallest index of job loss permanence at the 24-month mark but exhibit a larger loss permanence index than metropolitan counties at the 6-, 12-, and 18-month marks. This suggests a much stronger short cycle pattern in trade- and service-dominated counties relative to the more diversified metropolitan counties. Surprisingly, counties which are dominated by government employment also have a large job loss permanence index at 24 months. This result is aggravated by the fact that most counties, which fall into this category, have a very small employment base. As such, even small losses in employment are felt for an extended period of time. The large job loss index for both mining- and government-dominated counties reflects the lack of employment diversity and an inability of these economies to recapture job losses in other sectors.

A simple correlation index between average annual job growth, and the job loss permanence index suggests a moderate inverse relationship for early months, strengthening as the term of job loss is extended. At the 24 -month period, the simple correlation statistic is at -0.83 , providing additional evidence that job growth may hide underlying structural problems with short cycle trade and service employment. Annual average job growth in trade- and service-dominant counties is $44 \%$ higher than that for diversified metropolitan counties, but the 24 -month job loss permanence index is only $22 \%$ lower. As the trade and service industry matures in rural economies, growth in employment will begin to decelerate and one would expect to observe increases in the job loss permanence index in these trade- and service-dominated counties.

With regard to the index of job gain permanence in Table 4, counties dominated by government and mining employment have the smallest average index of job gain permanence, revealing a poor history of long-term job retention in these counties and suggesting that even small 
gains in employment are not captured for an extended period of time in these small nondiversified counties. Counties, which are dominated by trade and service employment, have the largest index of job gain permanence at the 1- and 6-month marks and second largest index value at the 12-, 18-, and 24-month marks. This result again suggests a stronger short cycle pattern in trade- and service-dominated counties relative to the more diversified metropolitan counties.

Given the differences in average annual job growth rates between trade- and service-dominant counties and metropolitan counties, there is some indication that as job growth slows, it is likely that some counties may experience a decrease in their job gain permanence. Simple correlation statistics between average annual employment growth rate and the job gain permanence index suggest a strong positive relationship $(0.73$ to 0.85$)$. The strength of this relationship diminishes slightly as the length of the job interval increases. This may suggest that diversification issues become more relevant than job growth in the long run and identifies a role for growth adjusted measures of employment risk.

Persistence Measures. The persistence analyses were performed for total employment for all the rural counties in Utah, for the period from January 1974 to December 1992. Table 5 presents the persistence measures for the five primary industry designations calculated using employment figures for each sector aggregated across all rural Utah counties. As would be expected, there are quite different persistence trends among these employment sectors, especially comparing across different "windows." These findings support the underlying argument of this study — that differing employment bases will differentially impact employment stability and, consequently, the economic well-being of counties.

More detailed analysis of the counties designated as specialized in various sectors is necessary to illustrate the specific impacts on rural labor markets. Tables 6-10 indicate the 
persistence measures for each of the counties categorized within the four primary employment sectors, as well as a table of those counties with no designation. Confidence intervals were developed and the corresponding significance levels are given. ${ }^{4}$ The results vary more than what was expected among the designations, which both illustrate the complexity of labor market issues and fuel interest in further research on the role of diversity within local economies. Nonetheless, some tendencies seem evident. First, mining counties appear to consistently rank among the highest persistence values in the long run, even though employment persistence within a shorter time frame is relatively low. Persistence trend results among other employment bases seem more mixed, especially among the trade and service counties.

Counties in the trade and service groups evidence the highest short-run persistence levels, with more mixed results in the long run. To understand the activity underlying these results, it is important to note several characteristics of particular counties and understand how these are exhibited in the persistence measures. The peaks associated with the annual cycles of tourism visitation will lead to persistence levels above one due to the fact that, once hiring has begun for a season, employment will only increase through the peak of the season (3-6 months), and decline with a substantial downsizing of the workforce at various tourism-related establishments. For this reason, it is not surprising to find the relatively high persistence measures within the 3- and 6-month windows, as well as subsequent peaks in future years (for example, the 18- and 30-month persistence levels for Grand County).

The diversity and nature of the trade and service sectors are also of interest. For example, Grand, Iron, and Washington Counties are trade- and service-dependent and classified as

\footnotetext{
${ }^{4}$ The confidence intervals were estimated using the standard errors calculations presented in Cochrane. The given confidence intervals were constructed at the $10 \%$ significance level.
} 
tourism-dependent by the UOPB. However, the persistence measures for these counties decline much less rapidly than for the other counties in the same group. Washington County has been a center for immigration of retirees from California and Nevada for the past decade. Similarly, Iron County has become increasingly impacted by these immigration patterns during the past five years. Our data suggest that Iron and Washington Counties' retail trade and service sectors are much more stable than those of the other counties, probably because retired households are not transient or seasonal. The results for Grand County are most likely a result of the significant change in the economic base during the data period. A Chi-squared test detected a break in the structure of the county in about $1983-84$, which coincides with the uranium bust. Thus, it is likely that some of the long-run persistence in that county can be attributed to its past mining-based economy.

Garfield, Summit, and Kane Counties are the most tourism-dependent, and, consistent with our hypothesis, low long-run employment persistence results are found for those counties. The rapid fall in persistence measures over the one-year cycle in these counties (often from above 1.0 to less than .10) suggests that an annual cycle dominates labor markets in these counties. The less pronounced employment cycles in the mining and manufacturing sectors (a consistent decline to .5 in the first 12 months) appears to indicate that growth-adjusted employment persistence in those sectors is more stable, at least over the intermediate run of 1-2 years.

Manufacturing counties are mixed, with Cache and Sanpete showing significantly less persistence and the other counties showing significantly higher persistence. Both of these counties do have relatively high employment in the government category; Cache County contains Utah State University, which employs approximately $17 \%$ of total county workers. Sanpete County has a relatively small employment base, so that relatively few employers in manufacturing dominate the “economic base." Further analysis of the relationships among various sectors within a county and 
employment stability appears warranted. Government-based counties exhibit few significant persistence measures, an expected result given the low absolute number of jobs in those counties. In short, only those counties dominated by mining or trade and service industries exhibit unique employment stability patterns (low growth/low volatility and high growth/high volatility, respectively). Other sectors' labor markets and diverse economies appear less dynamic in nature.

It is not surprising that certain industries have consistently increased or decreased their share of employment in rural labor markets, as these trends are evident throughout much of the United States. However, the consequences of prescribing and implementing new economic development strategies are more complex than simple job loss or creation. The job gain/loss heuristic illustrates the permanence of labor market dynamics, a point supported by previous analyses of structural change in similar economies. However, the persistence measures demonstrate the cyclical conditions underlying these changing labor markets while controlling the differential rates of employment growth.

\section{Conclusions}

Results from the two empirical analyses provide evidence to support previous hypotheses about tourism-based economies: a nondiversified development strategy that increases dependence on trade and service sector employment has the potential of increasing the risk of employment instability. This result is likely to be strengthened as recreation and tourism industries mature and the effects of dominant short-run cycles become more pronounced. This may explain why concerns about recreation and tourism-dependent rural development schemes appear relatively benign in employment growth phases but should be incorporated into community expectations about potential long-term impacts. 
Neumann and Topel found that diversified economies were more likely to exhibit employment stability, regardless of the dominant employment sector. This finding, together with the mixed results among many of the sectors, illustrates the need for careful analysis of the role diversification plays in reducing employment risk. This is particularly true in the trade and service sectors as they approach market maturity. While it appears that job growth has masked many of the adverse impacts of dominant short cycles, it is likely that a reduction in employment growth will manifest stronger residual employment risk impacts in nondiversified rural economies.

Employment creation and retention are often the most visible tenets of economic development. Our analysis lends support to the argument that rural development schemes must address employment persistence and the permanence of job gains and losses, as well as growth. This study complements previous studies of rural employment cycles, but, more importantly, illustrates the need for additional research on rural labor markets and their role in contributing or detracting from long-run strategic objectives of rural economic development plans. 


\section{Literature Cited}

Barkley, D.L. "The Economics of Change in Rural America." American Journal of Agricultural Economics 77(5, 1995):1252-8.

Bergstrom, J., H.K. Cordell, G. Ashley, and A. Watson. "Economic Impacts of Recreational Spending on Rural Areas: A Case Study." Economic Development Quarterly 4(1, February 1990a):29-39.

. "Economic Impacts of State Parks on State Economies in the South." Southern Journal of Agricultural Economics 29(1990b):69-78.

Brown, D.J., and J. Pheasant. "Sources of Cyclic Employment Instability in Rural Counties." American Journal of Agricultural Economics 69(4, 1987):819-27.

Chadwick, R.A. “Concepts, Definitions, and Measures used in Travel and Tourism Research.” In Travel, Tourism and Hospitality Research: A Handbookfor Managers and Researchers, eds. J.R.B. Ritchie, and C.R. Goeldner, pp. 47-59, New York: John Wiley and Sons, 1987.

Clark, G.L., M.S. Gertler, and J. Whiteman. Regional Dynamics: Studies in Adjustment Theory. Boston: Allen and Unwin, 1986.

Cochrane, J.H. "How Big is the Random Walk in GNP?" Journal of Political Economy 96(5, 1988):893-920.

Cordell, H.K., J. Bergstrom, and A. Watson. "Economic Growth and Interdependence Effects of State Park Visitation in Local and State Economies" Journal of Leisure Research 24(3, 1989):253-68.

Dawson, S., D. Blahna, and J. Keith. "Expected and Actual Regional Economic Impacts of Great Basin National Park." Journal of Park and Recreation Administration 11(4, Winter, 1993):45-59.

Drabenstott, M. "Rural Development: Implications of Structural Change for Policies and Institutions: Discussion.” American Journal of Agricultural Economics 77(5, 1995):1271-3.

Glasmeier, A.K., and M. Holland. "Service-Led Rural Development: Definitions, Theories and Empirical Evidence." International Regional Science Review 16(Spring/Summer 1994):197-229.

Fawson, C., J. Keith, and T. Chang. "Employment Stability and Structural Change in Resource Dependent Rural Utah Economies.” Journal of Leisure Research 28(2, 1996): 96-107.

Keith, J., and C. Fawson. "Economic Development in Rural Utah: Is Wilderness Recreation the Answer?" Annals of Regional Science 29(3, 1995):303-14. 
Kraybill, D.S., and B.A. Weber "Institutional Change and Economic Development in Rural America." American Journal of Agricultural Economics 77(5, 1995):1265-70.

Markley, D.M., and K.T. McNamara. "Sustaining Rural Economic Opportunity." American Journal of Agricultural Economics 77(5, 1995):1259-64.

Neumann, G.R., and R.H. Topel. "Employment Risk, Diversification, and Unemployment." The Quarterly Journal of Economics 105(1991): 1341-65.

Powers, T.M. "Wildland Preservation and the Economy of Utah." Paper prepared for Project 2000, Coalition for Utah's Future, Wilderness Task Force, University of Montana, Missoula, Montana, 1990.

. “The Wealth of Nature." Issues in Science and Technology 12(3, 1996):48-54.

Rudzitis, G., and H.E. Johansen. "Amenities, Migration, and Nonmetropolitan Regional Development." Report to the National Science Foundation, Department of Geography, University of Idaho, Moscow, Idaho, 1989.

United States Department of Agriculture (USDA), Economic Research Service. County Typology Codes. 1989. http://usda.mannlib.cornell.edu/data-sets/rural/86005/3/typol89.doc.

Utah State Office of Planning and Budget (USOPB). "Utah Tourism Financing: A Status Report From the Governor's Tourism Finance Committee." Demographic and Economic Analysis Section, February 3, 1995. 
Table 1. Employment Percentages, 1974 through 1992

\begin{tabular}{|c|c|c|c|c|c|c|c|c|c|c|}
\hline County & Mining & $\begin{array}{l}\text { Construc- } \\
\text { tion }\end{array}$ & $\begin{array}{l}\text { Manufact. } \\
\text { Durables }\end{array}$ & $\begin{array}{l}\text { Trans./ } \\
\text { Com./Util. }\end{array}$ & Other & $\begin{array}{l}\text { State } \\
\text { Gov't. }\end{array}$ & $\begin{array}{l}\text { Local } \\
\text { Gov't. }\end{array}$ & $\begin{array}{l}\text { Retail } \\
\text { Trade }\end{array}$ & Service & $\begin{array}{l}\text { Diversity } \\
\text { Measure }\end{array}$ \\
\hline Beaver & 2.129566 & 4.966173 & 1.627127 & $13.97326^{*}$ & 12.21076 & 3.241972 & 24.74121 & $25.25639^{*}$ & 11.85252 & 17.33761 \\
\hline Box Elder & 0.111222 & 4.222096 & $44.98021^{*}$ & 1.707249 & 11.5387 & 1.167776 & 11.99236 & 15.83063 & 8.44975 & $26.54991 *$ \\
\hline Cache & 0.025304 & 5.004798 & 7.797171 & 2.636126 & 23.15244 & $21.74954^{*}$ & 9.829421 & 16.57956 & 13.22564 & 14.39108 \\
\hline Carbon & $22.26764 *$ & 3.601949 & 0.955073 & 6.849073 & 12.43964 & 6.241911 & 16.05307 & 17.69077 & 13.90051 & 14.40677 \\
\hline Dagget & 0.418365 & 4.936469 & 0.450408 & 6.529129 & 28.87405 & 9.512511 & $24.11712^{*}$ & 13.62542 & 11.53653 & 20.77279 \\
\hline Davis & 0.086971 & 5.080661 & 8.664738 & 3.335091 & $42.43212^{*}$ & 0.49317 & 11.22103 & 15.52431 & 13.16191 & 17.82419 \\
\hline Duchesne & $20.00906 *$ & 5.610847 & 1.415678 & 7.202994 & 14.97334 & 2.010166 & 22.53685 & 17.35397 & 8.857428 & 15.43367 \\
\hline Emery & 32.70433* & $15.33878^{*}$ & 0.243344 & $16.61144^{*}$ & 3.210082 & 1.493009 & 15.27605 & 8.586939 & 6.536025 & $21.5472 *$ \\
\hline Garfield & 5.685933 & 3.667531 & 14.53568 & 4.231015 & 13.17518 & 3.951159 & 17.67702 & 11.90678 & $25.16969 *$ & 15.80517 \\
\hline Grand & $15.5241^{*}$ & 7.828017 & 1.888764 & 8.746147 & 14.37501 & 2.390961 & 11.3062 & 16.80952 & 14.44688 & $11.4419^{\wedge}$ \\
\hline Iron & 2.838924 & 5.257156 & 3.280599 & 5.773947 & 15.71218 & $13.72623 *$ & 12.36568 & $25.38535^{*}$ & 15.65994 & 13.99156 \\
\hline Juab & 4.642626 & 5.237383 & 3.01765 & 2.13183 & 23.72931 & 2.460403 & 23.19367 & $23.27136 *$ & 12.31577 & 17.14531 \\
\hline Kane & 1.41631 & 1.726709 & 1.524925 & 6.010061 & 11.92325 & 4.625942 & 19.54285 & $28.61701^{*}$ & 24.61294* & 19.92999 \\
\hline Millard & 4.25471 & $11.30215^{*}$ & 2.041655 & $12.49772 *$ & 16.17321 & 2.632822 & 21.90455 & 19.74573 & 9.447461 & 15.66054 \\
\hline Morgan & 1.048499 & 6.194518 & $24.34945^{*}$ & 1.900376 & 23.48078 & 2.188695 & 22.74644 & 13.28202 & 4.809221 & 17.33618 \\
\hline Piute & 5.253902 & 4.672435 & 1.010301 & 3.794057 & 18.62422 & 9.271037 & $43.83041^{*}$ & 9.727877 & 3.815768 & $24.76219^{*}$ \\
\hline Rich & 1.272676 & 1.574887 & 0.859317 & 3.117383 & 14.96561 & 7.572472 & 36.77999* & 14.50192 & 19.35574 & $21.77728^{*}$ \\
\hline Salt Lake & 1.623095 & 5.158966 & 10.46971 & 7.678804 & 21.51914 & 6.790605 & 7.598135 & 17.9512 & 21.18377 & $12.20802^{\wedge}$ \\
\hline San Juan & $22.44238^{*}$ & 4.402986 & 2.755029 & 4.955706 & 10.69316 & 4.596342 & 23.49932 & 11.59334 & 15.06172 & 16.54801 \\
\hline Sanpete & 0.261868 & 4.355893 & 7.335278 & 2.638673 & 24.7466 & 13.9798* & 20.55636 & 15.39334 & 10.71958 & 14.5492 \\
\hline Sevier & 6.616204 & 6.463273 & 5.569617 & 7.331047 & 17.51194 & 4.027185 & 15.75039 & 22.32186 & 14.40848 & $12.45901^{\wedge}$ \\
\hline Summit & 7.422105 & 5.174781 & 4.037762 & 3.811991 & 11.36534 & 1.700259 & 13.10824 & $24.68242 *$ & $28.6939^{*}$ & 18.85307 \\
\hline Tooele & 3.650628 & 4.318692 & 1.246939 & 2.437075 & $59.60244 *$ & 0.799084 & 10.16719 & 10.3866 & 7.356359 & $28.11063^{*}$ \\
\hline Uintah & $20.01289^{*}$ & 5.543059 & 2.237044 & 8.208066 & 12.23295 & 1.866263 & 12.85394 & 16.94589 & 20.09989 & 14.43018 \\
\hline Utah & 0.327313 & 4.772225 & 13.04401 & 3.327534 & 11.63005 & 4.298211 & 11.44612 & 18.54278 & $32.61176^{*}$ & 18.27383 \\
\hline Wasatch & 1.373066 & $11.50148^{*}$ & 3.103747 & 2.318007 & 13.04009 & 4.182283 & 23.23517 & 21.83117 & 19.40987 & 16.88313 \\
\hline Washington & 0.766759 & 7.395975 & 3.602853 & 4.153905 & 17.15238 & 5.575399 & 13.8109 & $26.97594 *$ & 20.56589 & 15.6573 \\
\hline Wayne & 5.736717 & $11.06992 *$ & 3.326263 & 1.013796 & 26.43108 & 5.156345 & $27.65795^{*}$ & 11.56362 & 8.044304 & 16.79499 \\
\hline Weber & 0.126891 & 4.335701 & 8.672436 & 5.005445 & 25.85995 & 5.621994 & 10.42006 & 20.09656 & 19.86077 & $13.03783^{\wedge}$ \\
\hline Mean & 6.55345 & 5.886742 & 6.346303 & 5.514723 & 19.06121 & 5.287019 & 18.45578 & 17.65449 & 15.00586 & 17.3765 \\
\hline St. Dev. & 8.727987 & 2.986272 & 9.135347 & 3.759855 & 10.88225 & 4.681314 & 8.284154 & 5.416516 & 7.13621 & 4.123951 \\
\hline Upper & 15.28144 & 8.873014 & 15.48165 & 9.274577 & 29.94345 & 9.968333 & 26.73994 & 23.07101 & 22.14207 & 21.50045 \\
\hline
\end{tabular}

*One standard deviation above mean statewide employment in sector.

^One standard deviation below mean statewide diversity in sector. 
Table 2. Grouping of Counties by Dominant Sector

\begin{tabular}{|c|c|c|c|c|c|}
\hline Mining & Construction & $\begin{array}{l}\text { Durables } \\
\text { Manufac- } \\
\text { turing }\end{array}$ & $\begin{array}{l}\text { Transport., } \\
\text { Commun., } \\
\text { \& Utilities }\end{array}$ & $\begin{array}{l}\text { Local \& } \\
\text { State } \\
\text { Government }\end{array}$ & $\begin{array}{l}\text { Services/ } \\
\text { Retail } \\
\text { Trade }\end{array}$ \\
\hline $\begin{array}{l}\text { Carbon } \\
\text { Duchesne } \\
\text { Emery } \\
\text { Grand } \\
\text { San Juan } \\
\text { Uintah }\end{array}$ & $\begin{array}{l}\text { Emery } \\
\text { Millard } \\
\text { Wasatch } \\
\text { Wayne }\end{array}$ & $\begin{array}{l}\text { Box Elder } \\
\text { Morgan }\end{array}$ & $\begin{array}{l}\text { Beaver } \\
\text { Emery } \\
\text { Millard }\end{array}$ & $\begin{array}{l}\text { Cache } \\
\text { Daggett } \\
\text { Iron } \\
\text { Piute } \\
\text { Rich } \\
\text { Sanpete } \\
\text { Washington }\end{array}$ & $\begin{array}{l}\text { Beaver } \\
\text { Garfield } \\
\text { Iron } \\
\text { Juab } \\
\text { Kane } \\
\text { Summit }\end{array}$ \\
\hline
\end{tabular}

Table 3. Persistence Measures for Rural Utah Counties, by Dominant Industries

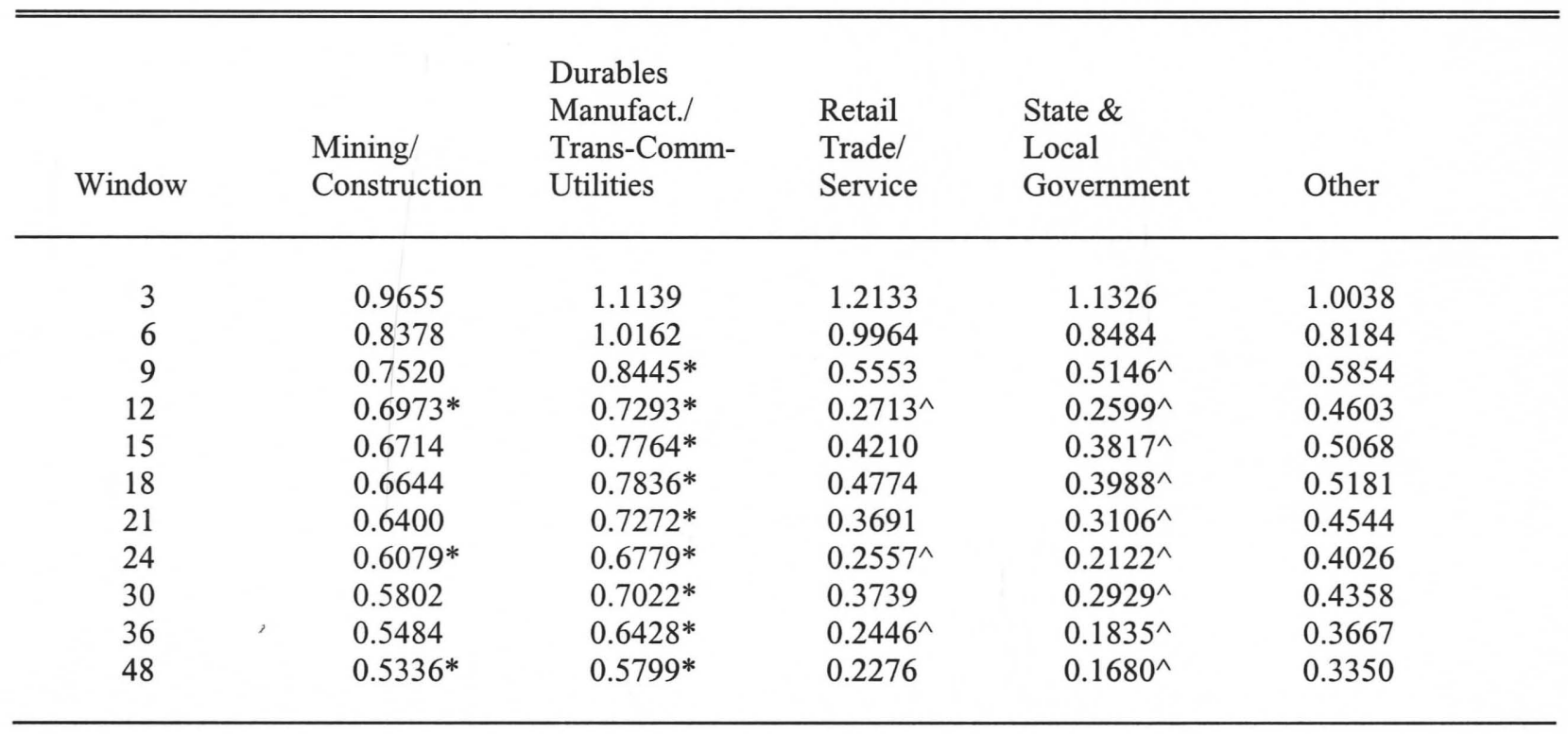

*One standard deviation above mean sector persistence.

${ }^{\wedge}$ One standard deviation below mean sector persistence. 
Table 4. Persistence Measures for Rural Utah Counties, Designated Mining (M)/ Construction (C) Counties

\begin{tabular}{|c|c|c|c|c|c|c|c|c|c|}
\hline $\begin{array}{l}\text { Window } \\
\text { (M) }\end{array}$ & $\begin{array}{l}\text { Carbon } \\
\text { (M) }\end{array}$ & $\begin{array}{l}\text { Duchesne } \\
(\mathrm{M}, \mathrm{C})\end{array}$ & $\begin{array}{l}\text { Emery } \\
\text { (M) }\end{array}$ & $\begin{array}{l}\text { Grand } \\
\text { (C) }\end{array}$ & $\begin{array}{l}\text { Millard } \\
\text { (M) }\end{array}$ & $\begin{array}{l}\text { San Juan } \\
\text { (C) }\end{array}$ & $\begin{array}{l}\text { Wasatch } \\
\text { (C) }\end{array}$ & $\begin{array}{l}\text { Wayne } \\
\text { (M) }\end{array}$ & Uintah \\
\hline 3 & 0.7896 & $1.2921^{*}$ & 0.8941 & $1.7733 * *$ & 1.4986 & $0.7704^{\wedge}$ & $1.6281^{* *}$ & 1.2318 & 1.2220 \\
\hline 6 & 0.5070 & $1.0938 * *$ & 0.7526 & $1.7225^{* *}$ & $1.8630 * *$ & $0.4205^{\wedge \wedge}$ & $1.4572 * *$ & $1.1387 * *$ & $1.1599 * *$ \\
\hline 9 & 0.4796 & $0.9047 * *$ & 0.6603 & $0.8045^{* *}$ & $2.0990 * *$ & 0.3657 & 0.6717 & 0.6538 & $0.8868 * *$ \\
\hline 12 & $0.4424 * *$ & $0.7655^{* *}$ & $0.6542 * *$ & 0.3290 & $2.4502 * *$ & 0.2099 & 0.2555 & 0.3647 & $0.6868 * *$ \\
\hline 15 & 0.4825 & $0.8478 * *$ & $0.6751^{*}$ & 0.6298 & $2.9234 * *$ & 0.2891 & 0.5216 & 0.4363 & $0.8890 * *$ \\
\hline 18 & 0.4744 & $0.8589 * *$ & 0.6854 & $0.8235^{* *}$ & $3.2820 * *$ & 0.2716 & 0.6655 & 0.4585 & $0.9861 * *$ \\
\hline 21 & 0.4781 & $0.8356^{* *}$ & $0.6589^{*}$ & 0.6008 & $3.4961 * *$ & 0.2690 & 0.4492 & 0.3343 & $0.9152 * *$ \\
\hline 24 & 0.4486 & $0.7737 * *$ & $0.6371 * *$ & 0.4255 & $3.6702 * *$ & 0.2064 & 0.2770 & 0.2417 & $0.8152 * *$ \\
\hline 27 & 0.4852 & $0.8240 * *$ & $0.6500 *$ & 0.5975 & $3.8586 * *$ & 0.2480 & 0.4058 & 0.3123 & $0.8992 * *$ \\
\hline 30 & 0.4794 & $0.8230 * *$ & 0.6411 & $0.7211 * *$ & $3.9471 * *$ & 0.2424 & 0.4978 & 0.3580 & $0.9532 * *$ \\
\hline 33 & 0.4991 & $0.8272 * *$ & 0.6142 & 0.6034 & $3.9348 * *$ & 0.2436 & 0.3753 & 0.3090 & $0.9274 * *$ \\
\hline 36 & 0.4968 & $0.8137 * *$ & $0.5828 * *$ & 0.5051 & $3.8756 * *$ & 0.2124 & 0.2637 & 0.2578 & $0.8943 * *$ \\
\hline 39 & 0.5086 & $0.8478 * *$ & 0.5582 & $0.6315^{*}$ & $3.8222 * *$ & 0.2449 & 0.3549 & 0.3092 & $0.9886 * *$ \\
\hline 42 & 0.5332 & $0.8495 * *$ & 0.5774 & $0.7192 * *$ & $3.7391 * *$ & 0.2445 & 0.4308 & 0.3209 & $1.0679 * *$ \\
\hline 45 & 0.5593 & $0.8413 * *$ & 0.5740 & $0.6342 *$ & $3.6229 * *$ & 0.2514 & 0.3539 & 0.2608 & $1.0740 * *$ \\
\hline 48 & $0.5599 *$ & $0.8311 * *$ & $0.5639^{*}$ & $0.5639 *$ & $3.4944 * *$ & 0.2300 & 0.2703 & 0.2117 & $1.0681 * *$ \\
\hline
\end{tabular}

Note: $* *$ Above average persistence at the $10 \%$ significance level.

*Above average persistence at the $20 \%$ significance level.

$\wedge^{\wedge}$ Below average persistence at the $10 \%$ significance level.

${ }^{\wedge}$ Below average persistence at the $20 \%$ significance level.

Table 5. Persistence Measures for Rural Utah Counties, Designated Durables Manufacturing (D)/Trans.-Com.-Utility (TCU) Counties

\begin{tabular}{|c|c|c|c|c|c|}
\hline $\begin{array}{l}\text { Window } \\
\text { (TCU) }\end{array}$ & $\begin{array}{l}\text { Beaver } \\
\text { (D) }\end{array}$ & $\begin{array}{l}\text { Box Elder } \\
\text { (TCU) }\end{array}$ & $\begin{array}{l}\text { Emery } \\
\text { (TCU) }\end{array}$ & $\begin{array}{l}\text { Millard } \\
\text { (D) }\end{array}$ & Morgan \\
\hline 3 & $1.4174 * *$ & 1.2418 & 0.8941 & 1.4986 & 0.9588 \\
\hline 6 & $1.4589 * *$ & $0.9812 *$ & 0.7526 & $1.8630 * *$ & 0.8579 \\
\hline 9 & $0.9408 * *$ & $0.7656^{*}$ & 0.6603 & $2.0990 * *$ & 0.6994 \\
\hline 12 & $0.6304 * *$ & $0.5317 * *$ & $0.6542 * *$ & $2.4502^{* *}$ & $0.5875^{* *}$ \\
\hline 15 & $0.7279 * *$ & 0.6348 & $0.6751^{*}$ & $2.9234 * *$ & 0.6407 \\
\hline 18 & $0.7736^{* *}$ & 0.6284 & 0.6854 & $3.2820 * *$ & 0.6927 \\
\hline 21 & 0.5959 & 0.5538 & $0.6589^{*}$ & $3.4961 * *$ & $0.6557^{*}$ \\
\hline 24 & $0.4773 *$ & $0.4631 *$ & $0.6371 * *$ & $3.6702 * *$ & $0.6211^{* *}$ \\
\hline 27 & 0.5551 & 0.5655 & $0.6500^{*}$ & $3.8586 * *$ & $0.6661^{*}$ \\
\hline 30 & 0.6053 & 0.6029 & 0.6411 & $3.9471 * *$ & $0.6953^{*}$ \\
\hline 33 & 0.5015 & 0.5915 & 0.6142 & $3.9348 * *$ & $0.6645^{*}$ \\
\hline 36 & 0.4040 & $0.5537^{*}$ & $0.5828 * *$ & $3.8756 * *$ & $0.6397 * *$ \\
\hline 39 & 0.4399 & 0.5775 & 0.5582 & $3.8222 * *$ & $0.6360 *$ \\
\hline 42 & 0.4758 & 0.5421 & 0.5774 & $3.7391 * *$ & 0.6419 \\
\hline 45 & 0.3932 & 0.4760 & 0.5740 & $3.6229 * *$ & 0.6068 \\
\hline 48 & 0.3142 & 0.4065 & $0.5639^{*}$ & $3.4944 * *$ & $0.5824^{*}$ \\
\hline
\end{tabular}


Table 6. Persistence Measures for Rural Utah Counties, Designated Retail Trade (R)/ Service (S) Counties

\begin{tabular}{|c|c|c|c|c|c|c|c|}
\hline $\begin{array}{l}\text { Window } \\
\text { (R) }\end{array}$ & $\begin{array}{l}\text { Beaver } \\
\text { (S) }\end{array}$ & $\begin{array}{l}\text { Garfield } \\
\text { (R) }\end{array}$ & $\begin{array}{l}\text { Iron } \\
(\mathrm{R})\end{array}$ & $\begin{array}{l}\text { Juab } \\
(R, S)\end{array}$ & $\begin{array}{l}\text { Kane } \\
(\mathrm{R}, \mathrm{S})\end{array}$ & $\begin{array}{l}\text { Summit } \\
\text { (R) }\end{array}$ & Washington \\
\hline 3 & $1.4174 * *$ & $2.0603^{* *}$ & 0.8725 & 1.1057 & $2.0447 * *$ & $1.5777 * *$ & 1.1488 \\
\hline 6 & $1.4589 * *$ & $2.0041 * *$ & 0.6939 & 0.8306 & $2.0094 * *$ & $1.1198 * *$ & 0.7547 \\
\hline 9 & $0.9408 * *$ & $0.7445^{*}$ & 0.5765 & 0.6674 & 0.7282 & 0.5583 & 0.7342 \\
\hline 12 & $0.6304 * *$ & $0.1037^{\wedge \wedge}$ & $0.4178^{* *}$ & $0.5058^{* *}$ & $0.0698^{\wedge \wedge}$ & $0.0359^{\wedge \wedge}$ & $0.6287^{* *}$ \\
\hline 15 & $0.7279 * *$ & 0.4823 & 0.5035 & 0.4683 & 0.4311 & 0.3402 & $0.7963 * *$ \\
\hline 18 & $0.7736^{* *}$ & $0.7242 *$ & 0.5402 & 0.4479 & 0.6691 & 0.3845 & $0.8616^{* *}$ \\
\hline 21 & 0.5959 & 0.3618 & 0.5273 & 0.4267 & 0.3135 & 0.2397 & $0.9359 * *$ \\
\hline 24 & $0.4773^{*}$ & $0.0997^{\wedge}$ & $0.4672 *$ & 0.3809 & $0.0451^{\wedge \wedge}$ & $0.0244^{\wedge}$ & $0.9530 * *$ \\
\hline 27 & 0.5551 & 0.3048 & 0.5093 & 0.3952 & 0.2485 & 0.1862 & $1.0710 * *$ \\
\hline 30 & 0.6053 & 0.4640 & 0.5330 & 0.3961 & 0.4101 & 0.2215 & $1.1305^{* *}$ \\
\hline 33 & 0.5015 & 0.2538 & 0.5309 & 0.3842 & 0.2152 & 0.1462 & $1.1918 * *$ \\
\hline 36 & 0.4040 & 0.0849 & 0.4942 & 0.3658 & $0.0541^{\wedge}$ & $0.0183^{\wedge}$ & $1.2019 * *$ \\
\hline 39 & 0.4399 & 0.2296 & 0.5229 & 0.3746 & 0.1952 & 0.1261 & $1.2516 * *$ \\
\hline 42 & 0.4758 & 0.3462 & 0.5360 & 0.3856 & 0.3124 & 0.1527 & $1.2624 * *$ \\
\hline 45 & 0.3932 & 0.2018 & 0.5316 & 0.3734 & 0.1760 & 0.1050 & $1.2758 * *$ \\
\hline 48 & 0.3142 & 0.0816 & 0.4975 & 0.3544 & 0.0566 & $0.0177^{\wedge}$ & $1.2751^{* *}$ \\
\hline
\end{tabular}

Table 7. Persistence Measures for Rural Utah Counties, Designated Local (L)/State (S) Government Counties

\begin{tabular}{rlllllll}
\hline \hline $\begin{array}{l}\text { Window } \\
(\mathrm{S})\end{array}$ & $\begin{array}{l}\text { Cache } \\
(\mathrm{L})\end{array}$ & $\begin{array}{l}\text { Daggett } \\
(\mathrm{S})\end{array}$ & $\begin{array}{l}\text { Iron } \\
(\mathrm{L})\end{array}$ & $\begin{array}{l}\text { Piute } \\
(\mathrm{L})\end{array}$ & $\begin{array}{l}\text { Rich } \\
(\mathrm{S})\end{array}$ & $\begin{array}{l}\text { San Pete } \\
(\mathrm{L})\end{array}$ & Wayne \\
\hline 3 & 1.1167 & $1.5925^{* *}$ & 0.8725 & $0.7777^{\wedge}$ & $1.3590^{* *}$ & 0.9208 & 1.2318 \\
6 & 0.3988 & $1.2998^{* *}$ & 0.6939 & $0.4602^{\wedge}$ & $1.1058^{* *}$ & 0.5004 & $1.1387^{* *}$ \\
9 & 0.4307 & 0.5222 & 0.5765 & 0.4364 & 0.4908 & 0.3698 & 0.6538 \\
12 & 0.1173 & 0.1773 & $0.4178^{* *}$ & 0.3451 & $0.1343^{\wedge}$ & 0.1047 & 0.3647 \\
15 & 0.3242 & 0.3277 & 0.5035 & 0.3046 & 0.3132 & 0.2310 & 0.4363 \\
18 & 0.2276 & 0.4418 & 0.5402 & 0.2817 & 0.4151 & 0.2039 & 0.4585 \\
21 & 0.2757 & 0.2638 & 0.5273 & 0.2545 & 0.2429 & 0.1888 & 0.3343 \\
24 & 0.1522 & $0.1061^{\wedge}$ & $0.4672^{*}$ & 0.1910 & 0.1222 & 0.0801 & 0.2417 \\
27 & 0.2624 & 0.1688 & 0.5093 & 0.1685 & 0.2284 & 0.1531 & 0.3123 \\
30 & 0.2178 & 0.2766 & 0.5330 & 0.1365 & 0.2957 & 0.1469 & 0.3580 \\
33 & 0.2528 & 0.1695 & 0.5309 & 0.1295 & 0.1977 & 0.1373 & 0.3090 \\
36 & 0.1782 & 0.0813 & 0.4942 & 0.1375 & 0.1184 & 0.0705 & 0.2578 \\
39 & 0.2532 & 0.1391 & 0.5229 & 0.1484 & 0.2071 & 0.1063 & 0.3092 \\
42 & 0.2236 & 0.1960 & 0.5360 & 0.1326 & 0.2521 & 0.0995 & 0.3209 \\
45 & 0.2512 & 0.1423 & 0.5316 & 0.1456 & 0.1803 & 0.0948 & 0.2608 \\
48 & 0.2015 & 0.0803 & 0.4975 & 0.1223 & 0.1207 & 0.0488 & 0.2117 \\
\hline
\end{tabular}


Table 8. Persistence Measures, Other Counties

\begin{tabular}{|c|c|c|}
\hline Window & Sevier & Tooele \\
\hline 3 & $1.5678 * *$ & 1.0992 \\
\hline 6 & $1.4914^{* *}$ & 0.9941 \\
\hline 9 & 0.6546 & 0.7454 \\
\hline 12 & 0.1943 & 0.5948 \\
\hline 15 & 0.4342 & 0.5624 \\
\hline 18 & 0.5784 & 0.5249 \\
\hline 21 & 0.3582 & 0.4270 \\
\hline 24 & 0.1671 & 0.3524 \\
\hline 27 & 0.3204 & 0.3510 \\
\hline 30 & 0.4307 & 0.3313 \\
\hline 33 & 0.2803 & 0.2633 \\
\hline 36 & 0.1504 & 0.2114 \\
\hline 39 & 0.2693 & 0.2166 \\
\hline 42 & 0.3517 & 0.1851 \\
\hline 45 & 0.2554 & 0.1301 \\
\hline 48 & 0.1637 & 0.0801 \\
\hline
\end{tabular}

Note: Sevier is classified as a nondurables manufacturing county. Tooele is classified as a federal government county. 
Table 9. Cross-Section Analysis

\begin{tabular}{|c|c|c|c|c|c|c|c|c|c|c|c|c|c|}
\hline $\begin{array}{l}\text { Window } \\
\text { Width }\end{array}$ & Total & $\begin{array}{l}\text { Durable/ } \\
\text { Trans.- } \\
\text { Mining } \\
\text { Construc }\end{array}$ & $\begin{array}{l}\text { Manufac- } \\
\text { Comm.- } \\
\text { Utilities }\end{array}$ & $\begin{array}{l}\text { Non- } \\
\text { durables }\end{array}$ & $\begin{array}{l}\text { Retail } \\
\text { Whole/ } \\
\text { FIRE }\end{array}$ & $\begin{array}{l}\text { Federal } \\
\text { Trade/ } \\
\text { Services }\end{array}$ & $\begin{array}{l}\text { State \& } \\
\text { Govern- } \\
\text { ment }\end{array}$ & $\begin{array}{l}\text { Local } \\
\text { Govern. }\end{array}$ & $\begin{array}{l}\text { No } \\
\text { Other }\end{array}$ & Mean & $\begin{array}{l}\text { Standard } \\
\text { Deviation }\end{array}$ & Upper & Lower \\
\hline 3 & $1.2733 *$ & 0.9655 & 1.1139 & $0.9211^{\wedge}$ & $0.8499^{\wedge}$ & 1.2133 & 1.2404 & 1.1326 & 1.0038 & 1.0887 & 0.1583 & 1.2471 & 0.9304 \\
\hline 6 & $1.0515^{*}$ & 0.8378 & 1.0162 & $0.7363^{\wedge}$ & $0.6814^{\wedge}$ & 0.9964 & 1.0375 & 0.8484 & 0.8184 & 0.9007 & 0.1443 & 1.0450 & 0.7564 \\
\hline 9 & 0.7053 & 0.7520 & $0.8445^{*}$ & 0.5913 & 0.5827 & 0.5553 & 0.5821 & $0.5146^{\wedge}$ & 0.5854 & 0.6410 & 0.1137 & 0.7547 & 0.5273 \\
\hline 12 & 0.4525 & 0.6973* & 0.7293* & 0.5109 & 0.5234 & $0.2713^{\wedge}$ & 0.3465 & $0.2599^{\wedge}$ & 0.4603 & 0.4739 & 0.1783 & 0.6522 & 0.2956 \\
\hline 15 & 0.6119 & 0.6714 & $0.7764^{*}$ & 0.5053 & 0.5313 & 0.4210 & 0.4839 & $0.3817^{\wedge}$ & 0.5068 & 0.5479 & 0.1317 & 0.6796 & 0.4162 \\
\hline 18 & 0.6702 & 0.6644 & $0.7836 *$ & 0.4900 & 0.5231 & 0.4774 & 0.5412 & $0.3988^{\wedge}$ & 0.5181 & 0.5686 & 0.1264 & 0.6950 & 0.4422 \\
\hline 21 & 0.5915 & 0.6400 & $0.7272 *$ & 0.4477 & 0.4907 & 0.3691 & 0.4248 & $0.3106^{\wedge}$ & 0.4544 & 0.5002 & 0.1419 & 0.6421 & 0.3583 \\
\hline 24 & 0.4910 & $0.6079 *$ & $0.6779 *$ & 0.4193 & 0.4620 & $0.2557^{\wedge}$ & 0.3264 & $0.2122^{\wedge}$ & 0.4026 & 0.4315 & 0.1632 & 0.5948 & 0.2683 \\
\hline 30 & 0.6205 & 0.5802 & $0.7022 *$ & 0.4202 & 0.4561 & 0.3739 & 0.4312 & $0.2929^{\wedge}$ & 0.4358 & 0.4846 & 0.1372 & 0.6218 & 0.3475 \\
\hline 36 & 0.5077 & 0.5484 & $0.6428^{*}$ & 0.3876 & 0.4159 & $0.2446^{\wedge}$ & 0.2967 & $0.1835^{\wedge}$ & 0.3667 & 0.4034 & 0.1579 & 0.5613 & 0.2455 \\
\hline 48 & 0.4820 & $0.5336^{*}$ & $0.5799 *$ & 0.3513 & 0.3785 & 0.2276 & 0.2753 & $0.1680^{\wedge}$ & 0.3350 & 0.3745 & 0.1482 & 0.5227 & 0.2263 \\
\hline
\end{tabular}

*One standard deviation above mean employment persistence across sector

${ }^{\wedge}$ One standard deviation below mean employment persistence across sector. 
Table 10. Utah Average Monthly Wage by Industry: 1986-1992

\begin{tabular}{|c|c|c|c|c|c|c|c|}
\hline \multirow[b]{2}{*}{ Industry } & \multirow[b]{2}{*}{1986} & \multicolumn{6}{|c|}{ Average Monthly Wage } \\
\hline & & 1987 & 1988 & 1989 & 1990 & 1991 & 1992 \\
\hline \multicolumn{7}{|l|}{ Total nonagri- } & $\$ 1,801$ \\
\hline Mining & 2,758 & 2,708 & 2,820 & 2,905 & 2,976 & 3,002 & 3,217 \\
\hline Construction & 1,636 & 1,665 & 1,742 & 1,799 & 1,843 & 1,917 & 1,878 \\
\hline Manufacturing & 1,864 & 1,896 & 1,968 & 2,009 & 2,066 & 2,125 & 2,246 \\
\hline \multicolumn{8}{|l|}{ Trans., comm., } \\
\hline Trade & 1,052 & 1,063 & 1,103 & 1,133 & 1,173 & 1,231 & 1,264 \\
\hline \multicolumn{8}{|l|}{ Finance, ins., \& } \\
\hline Services & 1,226 & 1,315 & 1,350 & 1,385 & 1,458 & 1,534 & 1,682 \\
\hline \multirow[t]{3}{*}{ Government } & 1,574 & 1,597 & 1,625 & 1,663 & 1,735 & 1,805 & 1,891 \\
\hline & \multicolumn{7}{|c|}{ Percentage Change } \\
\hline & $1986-87$ & $1987-88$ & $1988-89$ & 1989-90 & $1990-91$ & 1991-92 & \\
\hline \multicolumn{7}{|l|}{ Total nonagri- } & \\
\hline Mining & -1.8 & 4.1 & 3.0 & 2.4 & 0.9 & 7.2 & \\
\hline Construction & 1.8 & 4.6 & 3.3 & $2.4^{`}$ & 4.0 & -2.0 & \\
\hline Manufacturing & 1.7 & 3.8 & 2.1 & 2.8 & 2.9 & 5.7 & \\
\hline \multicolumn{7}{|l|}{ Trans., comm., } & \\
\hline \multicolumn{8}{|l|}{ Finance, ins., \& } \\
\hline real estate & 4.7 & 3.7 & 3.4 & 3.3 & 4.9 & 9.7 & \\
\hline Services & 7.3 & 2.7 & 2.6 & 5.3 & 5.2 & 9.6 & \\
\hline Government & 1.5 & 1.8 & 2.3 & 4.3 & 4.0 & 4.8 & \\
\hline
\end{tabular}

Source: Utah Department of Employment Security. 